\title{
Su Ürünleri Sektöründe Karşılaşılan İş Hastalıkları ve Meslek Hastalıkları
}

\author{
Occupational Diseases Encountered in Fishery Sector
}

\author{
Özlem AYDOĞAN
}

\begin{abstract}
ÖZET
Sürdürülebilir gıda üretimi, hızla artan dünya nüfusunun ihtiyaçlarının karşılanabilmesi için ana unsurlardan biridir. Su ürünleri, temel gıda bileșenlerinden biri olan, hayvansal protein kaynağıdır. Nüfus artıșıyla orantılı protein gereksinimi arttığından, su ürünleri sektörüne ilgi artmaktadır. Su ürünleri, avcılık ve yetiştiricilik yoluyla elde edilir. Ürünlerin tüketime hazır hale sunulmasında, işleme teknolojisi sektörün ayrılmaz bir parçası olmaktadır. Yem sektörü yetiştiricilikle doğrudan ilgili bir alandır. Üretim halkasının herhangi bir basamağında görev alan Su Ürünleri Mühendisleri ve sektördeki diğer elemanlar, meslek hastalıklarının neler olduğu hakkında fikir ve bilgi sahibi olmalıdır. Bu çalışmanın amacı, su ürünleri sektöründeki meslek hastalıklarını ayrıntılı olarak ele almak, bilincin artırılması ve önlemler hakkında bilgi vermektir.
\end{abstract}

Anahtar Kelimeler: Meslek Hastalıkları, Yetiştiricilik, Avcılık, İşleme, Su Ürünleri Mühendisliği

\section{ABSTRACT}

Sustainable food production is one of the main element for providing the needs of the rapidly growing world population. Seafood is a source of animal protein, one of the essential food components. Interest in the aquaculture sector is growing as the demand for protein increases in proportion to population. Seafood is obtained by fishing and aquaculture. Making seafood ready for consumption, processing technology becomes an inseparable part of the sector. The feed sector is a field directly related to the aquaculture. Aquaculture engineers and other staffs working in any stage of the production ring should be aware of the occupational diseases in the sector. The aim of this study is to discuss occupational diseases in detail, to raise awareness and to offer precautions in seafood sector.

Keywords: Occupational Diseases, Aquaculture, Fishing, Prosessing, Aquacultural Engineering

Özlem AYDOĞAN | aydogan@eng.ankara.edu.tr

Ankara Üniversitesi, Ziraat Fakültesi, 06130 Ankara, Türkiye

Ankara University, Faculty of Agriculture, 06130, Ankara, Turkey 


\section{GİRIŞ}

Hızla artan dünya nüfusunun gıda ihtiyacının karşılanabilmesi için, tarımsal üretimin yanında deniz ve iç sularda avlanma ve yetiştiricilik kapasitelerinin geliştirilerek su ürünleri miktarının arttırılması gereklidir. Yakın gelecekte, hayvansal protein gereksinimlerinin daha da artması ve bu talebinin yaklaşık yüzde 20' sinin su ürünlerinden karşılanması beklenmektedir[1].

Balık ve su ürünleri tüketimi kişi başı yıllık ortalaması; dünyada $18.9 \mathrm{~kg}$, Avrupa Birliğìnde $23.1 \mathrm{~kg}$, ülkemizde ise sadece $5.5 \mathrm{~kg} \operatorname{dır}[2]$. Üç tarafı denizlerle çevrili ülkemiz; yaygın iç su, çok sayıda doğal göl, baraj gölü ve nehirlere sahip olup, hem avcılık hem de yetiştiricilik açısından büyük potansiyele sahiptir. Su ürünleri ihracatı, ülkemiz ekonomisi için önemli olup, 2018 yılında 952 milyon \$' a ulaşmıştır. Su ürünleri yetiştiriciliği, Birleşmiş Milletler Gıda ve Tarım Örgütü (FAO) tarafindan dünyada en hızlı büyüyen gıda sektörü olarak belirlenmiştir. Sektörünün, 2017 yılı verilerine göre toplam su ürünleri dağılımının \% 56 ' sı avcılık, \% 44' ü yetiştiricilikten oluşmaktadır. Yetiştiriciliğin ülkemiz su ürünlerindeki payı \% 6 artarak \% 50' ye ulaşmış olup, toplam üretim; 2018 yılı için 628 bin ton’ dur[3].

Su ürünleri sektörü, balık ve diğer su canlılarının yetiştirilmesinden son ürün aşamasına kadar (taze, dondurulmuş, kurutulmuş, tütsülenmiş, salamura, konserve veya canlı) çok sayıda proses basamağı içeren bir sektördür. Su Ürünleri Mühendisi; tatlı ve tuzlu sularda bulunan balık, kabuklu canlı ve bitkilerin korunması, yetiştirilmesi, avlanması ve işlenmesi çalışmalarında bulunur. Balık çiftlikleri, su ürünleri işleme tesisleri ve balık yemi işletmelerinden sorumlu olup, sektörün hızlı yükseliş ve gelişme göstermesinde etkin role sahiptir[4]. İş sağlığı ve güvenliğì ne ilişkin tehlike sınıflarının yer aldığı tebliğ kapsamında "su ürünle- ri sektörü” tehlikeli olarak sınıflandırılmaktadır. Ekonomik faaliyet sınıflaması (NACE Rev. 2), balıkçılık ve su ürünleri yetiştiriciliğgini;

- deniz balıkçılığı

- tatlı su balıkçılığı

- deniz ürünleri yetiştiriciliği

- tatlı su ürünleri yetiştiriciliği

alt sınıflarına ayırmaktadır. Bu sınıflamaya göre 5510 sayılı kanunun 4-1/a maddesi kapsamındaki sigortalılardan iş kazası geçiren ve meslek hastalığına tutulan sigortalılara ait istatistikler Tablo 1' de görülmektedir. Balıkçlık ve su ürünleri yetiştiriciliğinde 2017 yılında, toplam 273 sigorta1 ç̧alışan, iş kazası geçirmiştir. Bu veriler balıkçlık açısından incelendiğinde, toplam 28 çalışan( 5 kadın, 23 erkek) iş kazasına uğrarken, yetiştiricilik sektöründe, 245 çalışan(19 kadın, 226 erkek) iş kazası geçirmiştir[5].

İş kazası; işyerinde veya işin yürütümü nedeniyle meydana gelen, ölüme sebebiyet veren veya vücut bütünlüğünü ruhen ya da bedenen engelli hâle getiren olaydır. Meslek hastalığı; mesleki risklere maruziyet sonucu ortaya çıan hastalık olarak tanımlanmaktadır[6]. Ülkemizde; işyerlerinde iş sağllğı ve güvenliğinin sağlanması, işveren ve çalışanların görev, yetki, sorumluluk, hak ve yükümlülüklerinin düzenlenmesi, 6631 sayılı kanun ile güvence altına alınmıştır. Mesleki risklerin önlenmesi ve bu risklerden korunmaya yönelik çalışmaları da kapsayacak, iş sağlığı ve güvenliği hizmetlerinin sunulması için işveren; iş güvenliği uzmanı ve iş yeri hekimi görevlendirir. Mesleki risk ve hastalıkların önlenebilmesi için, çalışanlar yapılan işin riskleri hakkında fikir ve bilgi sahibi olmalıdır. Sağlıklı toplumu, sağlıklı bireyler oluşturduğundan, çalışanların meslek hastalıkları ile karşılaşma derecesini asgari düzeye indirgemek hayati ve sosyal önem taşımaktadır. Bu çalışmada, su ürünleri sektöründe görev alan Su Ürünleri Mühendisleri ve diğer çall- 
Tablo 1: Balıkçılık ve su ürünleri yetiştiriciliği’ nde iş kazası geçiren ve meslek hastalığına tutulan sigortalıların dağılımı, 2017

\begin{tabular}{|c|c|c|c|c|c|c|c|c|c|c|c|c|c|c|c|c|c|c|c|}
\hline \multirow{3}{*}{\multicolumn{2}{|c|}{ Ekonomik faaliyet sınıflaması }} & \multicolumn{15}{|c|}{ İş göremezlik sürelerine(gün) göre iş kazası geçiren sigortalı sayıları } & \multirow{2}{*}{\multicolumn{3}{|c|}{$\begin{array}{c}\text { Meslek } \\
\text { hastalığına } \\
\text { tutulan } \\
\text { sigortalı sayısı }\end{array}$}} \\
\hline & & \multicolumn{6}{|c|}{ Erkek } & \multicolumn{6}{|c|}{ Kadın } & \multicolumn{3}{|c|}{ Toplam } & & & \\
\hline & & 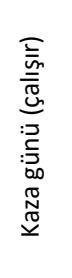 & 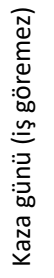 & 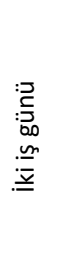 & 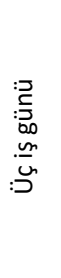 & 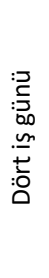 & 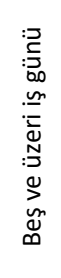 & 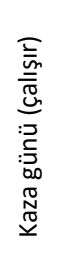 & 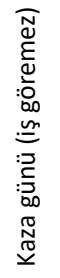 & 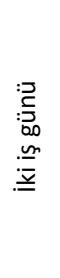 & 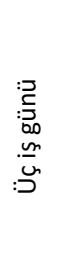 & 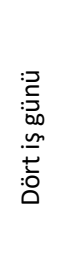 & 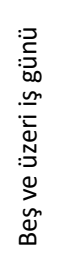 & 总 & $\begin{array}{l}\frac{5}{\overline{0}} \\
\stackrel{\sigma}{\check{0}}\end{array}$ & $\begin{array}{l}\varepsilon \\
\frac{\varepsilon}{\sigma} \\
\frac{0}{0} \\
\vdash\end{array}$ & 总 & $\begin{array}{l}\stackrel{\subseteq}{\overline{7}} \\
\stackrel{\mathbb{\pi}}{\underline{y}}\end{array}$ & $\begin{array}{l}\varepsilon \\
\frac{\varepsilon}{0} \\
\frac{\pi}{0} \\
\circ\end{array}$ \\
\hline \multicolumn{2}{|c|}{$\begin{array}{l}\text { Balıkçılık ve su ürünleri } \\
\text { yetiştiriciligí }\end{array}$} & 177 & 3 & 10 & 22 & 3 & 94 & 14 & 0 & 1 & 1 & 0 & 8 & 249 & 24 & 273 & 0 & 0 & 0 \\
\hline \multirow[t]{2}{*}{ Balıkçıık } & $\begin{array}{c}\text { Deniz } \\
\text { balıkçılığı }\end{array}$ & 9 & 0 & 0 & 1 & 0 & 4 & 2 & 0 & 0 & 0 & 0 & 1 & 14 & 3 & 17 & 0 & 0 & 0 \\
\hline & $\begin{array}{c}\text { Tatlısu } \\
\text { balıkçıığı }\end{array}$ & 2 & 1 & 0 & 0 & 0 & 6 & 1 & 0 & 0 & 0 & 0 & 1 & 9 & 2 & 11 & 0 & 0 & 0 \\
\hline \multirow[t]{2}{*}{ Yetiştiricilik } & $\begin{array}{l}\text { Deniz ürünleri } \\
\text { yetiştiriciliği }\end{array}$ & 102 & 2 & 9 & 18 & 2 & 77 & 9 & 0 & 1 & 1 & 0 & 3 & 210 & 14 & 224 & 0 & 0 & 0 \\
\hline & $\begin{array}{l}\text { Tatlı su ürünleri } \\
\text { yetiştiriciliği }\end{array}$ & 4 & 0 & 1 & 3 & 1 & 7 & 2 & 0 & 0 & 0 & 0 & 3 & 16 & 5 & 21 & 0 & 0 & 0 \\
\hline
\end{tabular}

şanlara (tekniker, balıkçı, işçi vb.) mesleklerindeki olası risk ve önlemler hakkında bilgi vermek, farkındalık oluşturmak amaçlanmıştır.

\section{MESLEK HASTALIĞI}

Ülkemizde 5510 sayılı SGK Kanunu’ nun 14. Maddesine göre meslek hastalığı; sigortalının çalıştığı veya yaptığı işin niteliğinden dolayı tekrarlanan bir sebeple veya işin yürütüm şartları yüzünden uğradığı geçici veya sürekli hastalık, bedensel veya ruhsal özürlülük halleridir[7].

Meslek hastalığına sebep olan etkenler Tablo 2' da özetlenmiştir. Bir hastalığın meslek hastalığı olarak tanımlanabilmesi için tıbbi ve yasal olarak hastalığın mesleki maruziyete bağlı olması, hastalık ve meslek arasında sebepsonuç ilişkisinin kanıtlanmış olması gereklidir. Meslek hastalıklarının tipleri ve sınıflandırılması, neden-sonuç ilişkisinin kurulmasına ve hastalığın işin yürütüm koşullarına bağlı olup olmadığının belirlenmesine yardımcı olması açısından önemlidir. Uluslararası Çalışma Örgütü (ILO)’ ne göre meslek hastalıkları başlıca;

- Ajanlarla meydana gelen meslek hastalıkları (fiziksel, kimyasal ve biyolojik)

- Hedef organ ve sistemlerin meslek hastalıkları (solunum, deri, kas-iskelet)

- Mesleki kanser olarak sınıflandırılmıştır[7].

Mesleki kanser, genetik yatkınlık, sigara alışkanlığı, beslenme ve çevresel etkenlere bağlı olmakla birlikte yapılan işin niteliğinden kaynaklı olarak yıllar sonra ortaya çlkabilmektedir. Ülkemizde 2017 istatistiklerine göre 81 bin kişi kanser nedeniyle hayatını kaybetmiştir[8]. Emekli-

Tablo 2: Meslek hastalığı etkenleri

\begin{tabular}{cccc}
\hline Kimyasal & Fiziksel & Biyolojik & Psikolojik \\
\hline Ağır metal & Gürültü ve titreşim & Bakteri & Depresyon \\
Asit ve alkali maddeler & Yüksek basınç veya vakum & Virüs & Oturuş bozuklukları \\
Çözücü & Soğuk veya sıcak & Parazit & Şiddet eğilimi \\
Gaz & Düşme riski & Biyoteknoloji kaynaklı & Hipertansiyon \\
Pestisit & Toz & & Koroner sorunlar \\
& Radyasyon & & Yüksekte çalışma \\
\hline
\end{tabular}


lik yaşantısında kanser olduğunu öğrenen kişi, bunun işle bağlantılı olduğunu hatırlamaması mümkündür. Birçok etkenin birbiri ile ilintili olması mesleki kanser tanısı koymayı hem dünyada hem de ülkemizde güçleştirmektedir. Mesleki kanser tanısını koymak için; bazı gerekli kriterler bulunmaktadır. Bunlar;

- Kansorejen etkenle temas yıllar öncesine dayanabilir. Bazı durumlarda hasta tarafından anımsanmayabilir.

- Kanser, çoğunlukla eş zamanlı ve birbirini takip eden etkenlere bağlı olup, kişinin genetik yatkınlığına bağlı olarak farklı bireylerde etkenlerin farklı birleşimleri aynı kansere yol açabilir.

- Mesleki kanserler; ortaya çıkış ve gelişim evreleriyle, mesleki olmayanlardan ayırt edilemez $[9,10]$.

Burada önemli olan kişinin yaptığı iş hakkında bilinçli olması ve olası riskleri göz önünde bulundurmasıdır. Gerekli durumlarda iş yeri hekimi ile yaptığı işin niteliği hakkında bilgi alış verişinde bulunmalıdır.

\section{SU ÜRÜNLERİ SEKTÖRÜ}

Avcılık, yetiştiricilik ve işleme teknolojisi ana başlıkları altında su ürünleri sektöründe karşılaşılan meslek hastalıkları geniş dağılım göstermektedir. Örneğin, yetiştiricilik sektörü açısından yem kritik faktör olup, balık yemi sektöründe çalışanların karşılaşabileceği hastalıklarında dikkate alınmasında fayda vardır[11]. Avcılık faaliyetleri, zor hava koşullarında gerçekleştirilen, troller ve ağır ekipmanlarla çalışma gerektirdiğinden iş kazaları ve meslek hastalıklarından korunma önemlidir. Avcılıkta karşılaşılan boğulma; iş kazası olup, önlem olarak can kurtaran yeleği giyilmelidir. Su ürünleri sektöründe, makinaların kullanımı kaçınılmazdır. Mühendislikte, insan-makina-çevre etkileşimi ergonominin temelini oluşturmaktadır. Bazı meslek hastalıklarına, tüm mühendislik alanlarında rastlanmaktadır. Ergonomi kaynaklı en sık oluşan hastalıklar, kas iskelet sistemi rahatsızlıkları olup mühendislerin; balıkçların, teknisyenlerin karşılaşabilecekleri meslek hastalıkları arasındadır. Su ürünleri sektöründe çalışanların karşılaşabilecekleri meslek hastalıkları Tablo 3' de özetlenmiş, ilerleyen bölümlerde avcılık, yetiştiricilik-yem ve işleme sektörleri detaylı olarak ele alınmıştır.

\section{A. Avcılıkta Karşılaşabilecek İş Kazaları ve Meslek Has- talıkları}

Ülkemizde, 2017 su ürünleri istatistiklerine göre, avc1lık faaliyetlerinin \% 51' i deniz, \% 5' i tatlı sularda yapil-

Tablo 3: Su ürünleri sektöründe karşılaşılan meslek hastalıkları

\begin{tabular}{|c|c|c|c|c|}
\hline & $\begin{array}{l}\text { Avcılık } \\
\text { sektörüü }\end{array}$ & $\begin{array}{c}\text { Yetiştiricilik } \\
\text { sektörü }\end{array}$ & $\begin{array}{l}\text { İşleme } \\
\text { sektörü }\end{array}$ & $\begin{array}{c}\text { Yem } \\
\text { sektörü }\end{array}$ \\
\hline Kas iskelet sistemi hastalıkları & $\checkmark$ & $\checkmark$ & $\checkmark$ & $\checkmark$ \\
\hline İşitme kaybı & $\checkmark$ & $\checkmark$ & $\checkmark$ & $\checkmark$ \\
\hline Hiperbarik kaynaklı rahatsızlık(vurgun) & $\checkmark$ & $\checkmark$ & & \\
\hline Egzama(diğer dermatit hastalıkları) & $\checkmark$ & $\checkmark$ & $\checkmark$ & $\checkmark$ \\
\hline Alerji, enfeksiyon & & $\checkmark$ & $\checkmark$ & $\checkmark$ \\
\hline Sindirim sistemi hastalıkları(gastrit, ülser) & $\checkmark$ & $\checkmark$ & & \\
\hline Üriner sistem hastalıkları(prostat, idrar yolu, böbrek hastalıkları) & $\checkmark$ & $\checkmark$ & & \\
\hline Sinir sistemi hastalıkları(psikolojik rahatsızlıklar, depresyon, parkinson) & $\checkmark$ & $\checkmark$ & $\checkmark$ & $\checkmark$ \\
\hline Mesleki kanser(dudak, cilt, akciğer kanseri) & $\checkmark$ & $\checkmark$ & $\checkmark$ & $\checkmark$ \\
\hline Mesleki astım & $\checkmark$ & & $\checkmark$ & $\checkmark$ \\
\hline
\end{tabular}


maktadır[3]. Avcılık doğası gereği zor çalışma koşullarına sahip olduğundan, iş kazaları (sıkışma, burkulma, el-kol yaralanma ve kopması, boğulma vb.) kadar meslek hastalıklarıda (astım, kanser, işitme kaybı, enfeksiyon) ciddi sonuçlar doğurmaktadır[12]. Tablo 4' de 2015-2017 yılları arası deniz ve tatlı sularda avcllık faaliyetleri sırasında iş kazası geçiren ve meslek hastalığına tutulan çalışan sayıları görülmektedir[13]. İş kazasına uğrayan sigortalı sayısının arttığı görülmekte, 2016 yılında 2014 yılına kıyasla 3 kat fazla iş kazası ile karşılaşııışıtır. Meslek hastalığına yakalanan sigortalı sayısı belirlenememiştir. Bu durum meslek hastalıklarının uzun sürede ortaya çıkması, sonucu olabileceği gibi, çalışanların hastalık ile iş arasındaki bağlantıyı kuramamasından da kaynaklanmaktadır.

Dalgalı ve firtınalı ortamlarda yapılan avcılık faaliyetlerinde, harekete bağlı özellikle kas iskelet sistemine yük binmektedir. Bu durum bel omurlarında baskıya neden olmakta ve rahatsızlıklara (bel fitığı vb.) yol açmaktadır. A $\breve{g}-$ ların atılması-toplanması, balıkların ayrılması, kasalanması işlemleri esnasında el-kol, ayak-bacaklarda yüklenmeler yaşanmaktadır. Bir süre sonra eklemlerde sorunlar (ağrılı romatizma, menisküs vb.) ortaya çıkmaktadır. Avcılık, hava koşullarına bağlı olduğundan uzun süre soğuk ortamda çalışma sonucu karşılaşılan romatizmal hastalıklar mes- lek hastalıkları arasında yer almaktadır[12].

Solunum sistemi hastalıkları, bu sektörde sık rastlanılan meslek hastalıkları arasındadır. Ava gidiş, sabaha karşı yapılan av sırasında, dönüş yolunda, soğuk ve nemli hava koşulları uzun dönemde astım, bronşit, zatürre gibi hastalıklara neden olmaktadır. Ayrıca ürünlerinin tazeliğini koruması için yerinde dondurma yapılmaktadır. Trimetilamin, metil klorür, endotoksinler gibi kimyasal maddelere maruz kalma mesleki astım ve zehirleme riskini arttırmaktadır [11]. Özellikle gemilerin makine dairelerinde çalışan iş̧̧ilerin asbest ya da polisiklik aromatik hidrokarbonlara temasta kalması, akciğer kanseri riskini arttırdığı bilinmektedir.

Av faaliyetlerinin değişken, uzun süreli olması ve yüksek tempo gerektirmesi, öğün alışkanlıklarını etkilemekte, bu durum sindirim sistemi hastalıklarına (gastrit, ülser) yol açmaktadır. Genital ve üriner sistem hastalıkları, nemli ve rüzgarlı ortamda bulunma, korunaklı kamara imkanlarının az olması durumlarında, ortaya çıkan meslek hastalıkları arasındadır. Avcılıkta; prostat, idrar yolu ve böbrek hastalıklarıyla karşılaşma yüzdesi artmaktadır[12].

İşitme kaybı; teknelerin makina daireleriyle, vinç ve ağ çekme takımlarının bulunduğu alanlarda uzun süreli çalışanlarda görülmektedir. Küçük ve büyük ölçekli tekneler

Tablo 4: Avcılık açısından yıl bazında iş kazası geçiren ve meslek hastalığına tutulan sigortalı sayıları

\begin{tabular}{|c|c|c|c|c|c|c|c|c|c|c|c|c|}
\hline & \multicolumn{4}{|c|}{2015} & \multicolumn{4}{|c|}{2016} & \multicolumn{4}{|c|}{2017} \\
\hline & \multicolumn{2}{|c|}{$\begin{array}{l}\text { İş kazası geçiren } \\
\text { sigortalı sayısı }\end{array}$} & \multicolumn{2}{|c|}{$\begin{array}{c}\text { Meslek } \\
\text { hastalığına } \\
\text { tutulan sigortalı } \\
\text { sayısı }\end{array}$} & \multicolumn{2}{|c|}{$\begin{array}{l}\text { İş kazası geçiren } \\
\text { sigortalı sayısı }\end{array}$} & \multicolumn{2}{|c|}{$\begin{array}{c}\text { Meslek } \\
\text { hastalığına } \\
\text { tutulan sigortalı } \\
\text { sayısı }\end{array}$} & \multicolumn{2}{|c|}{$\begin{array}{l}\text { İş kazası geçiren } \\
\text { sigortalı sayısı }\end{array}$} & \multicolumn{2}{|c|}{$\begin{array}{c}\text { Meslek } \\
\text { hastalığına } \\
\text { tutulan sigortal } \\
\text { sayısı }\end{array}$} \\
\hline & 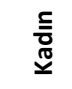 & 旁 & 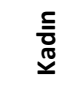 & 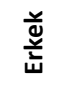 & 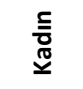 & 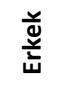 & 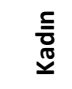 & 莺 & 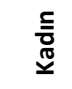 & 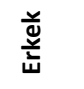 & 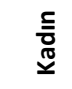 & 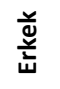 \\
\hline Deniz avcilı̆ı & 94 & 75 & 0 & 0 & 259 & 115 & 0 & 0 & 3 & 14 & 0 & 0 \\
\hline Tatlı su avcılığı & 5 & 8 & 0 & 0 & 1 & 9 & 0 & 0 & 2 & 9 & 0 & 0 \\
\hline AVCILIK (TOPLAM) & \multicolumn{2}{|c|}{182} & \multicolumn{2}{|c|}{0} & \multicolumn{2}{|c|}{384} & \multicolumn{2}{|c|}{0} & \multicolumn{2}{|c|}{28} & \multicolumn{2}{|c|}{0} \\
\hline
\end{tabular}


ile yapılan avcılık faaliyetlerinde motor gürültüsü ve titreşim; "vertigo", sinir sistemi hastalıkları (depresyon, parkinson) ve konsantrasyon eksikliğine neden olmaktadır. Ağır çalışma koşulları, toplumdan izole açık denizde bulunma, zihinsel ve ruhsal sorunlara yol açmaktadır. Avcılıkta, birçok meslekte görülen deri hastalıklarına (dermatit, egzama vb.) sıkça rastlanmaktadır. Nem, soğuk ve rüzgar deride tahrişe neden olmaktadır. Çizme kullanımı ayaklarda mantar oluşumunu hızlandırmaktadır. Ağlarda kullanılan kimyasal ve boyalar, alerjiye neden olmaktadır. Tuzlu su zerreleri, UV-1şınlarına maruz kalma; katarakt ve diğer göz hastalıklarına yol açmaktadır. Dudak kanseri; ağ saklamak için kullanılan katran'ın, ağlarla uğraşırken balıkçıların ağızlarını kullanması sonucu ortaya çıktığı düşünülen bir kanser türüdür. Bununla birlikte, UV-1şınlara maruz kalma ve sigara kullanımının, kanser riskini arttırdığı yönünde genel kanı bulunmaktadır. Ayrıca açık deniz koşullarının hijyenden uzak olması; ağız yaralarına, diş ve dişeti sorunlarına neden olmaktadır. Ağız ve diş problemleri, kalp-damar hastalıklarına yol açtığından mutlaka önemsenmelidir[12].

Sünger avcılı̆̆ı; denizlerimizde Bodrum, Marmaris ve Akdeniz kıyılarında yapılır. Deniz diplerinde kayalara yapışık olarak bulunan deniz süngeri avcılığı, keskin bir bıçak yardımı ile gerçekleştirilir. Halk arasında "vurgun” olarak bilinen dekompresyon hastalığı, meslek hastalığı sınıfına girmektedir. Dalgıç ve su altında çalışanlarda ani basınç değişimi nedeniyle ortaya çıkan; beyin, merkezi sinir sistemi ve omuriliği etkilemesi sonucu felç kalma riski bulunan fiziksel kaynaklı meslek hastalığıdır. Deniz seviyesinden, derinlere inildikçe basınç artışı görülür. Vurgun, deniz yüzeyine çıkarken meydana gelmektedir. Kızarmış bir cilt, kol-bacaklarda uyuşma, sendeleme, öksürük nöbeti, yığılıp kalma, şuur kaybı belirtileri bulunmaktadır[14].

\section{B. Yetiştiricilik ve Yem Sektöründe Karşılaşabilecek İş}

\section{Kazaları ve Meslek Hastalıkları}

Ülkemizde yetiştiricilik ilk olarak sazan ve gökkuşağ1 alabalığı ile başlamıştır. Daha sonra birim alan başına maksimum ürün ve damak tadı tercihi nedenleriyle çipura ve levrek yetiştiriciliği gelişmiştir[15]. Günümüzde, yetiştiriciliği en çok tercih edilen türler; alabalık(110 bin ton), levrek (100 bin ton), çipura(61 bin ton) olup, 2017 yılı istatistiklerine göre açık denizde 172 bin ton, iç sularda 104 bin ton, toplam 276 bin ton üretim gerçekleşmiştir[3, 16]. Sularımızda yetiştiricilik faaliyetleri, açık denizde (offshore) 426 adet, iç sularla (göl, baraj göleti, dalyan vb.) 1860 adet, toplam 2286 adet çiftlikte gerçekleştirilmektedir. Bu işletmelerin yıllık üretim kapasitesi 487 bin ton’ dur[3]. Sektördeki büyüme, çiftlik tesislerini artırmasının yanında çalışan sayısını da artırmış, bu durum yaşanan iş kazalarını da beraberinde getirmiştir. İş kazası geçiren sigortalı sayısı, 2016 yılında yaklaşık 3 kat artmıştır (Şekil 2).

\section{Şekil 2: Yetiştiricilik kapasitesi ile 2012-2016 yılları} arası iş kazası geçiren sigortalı sayısı

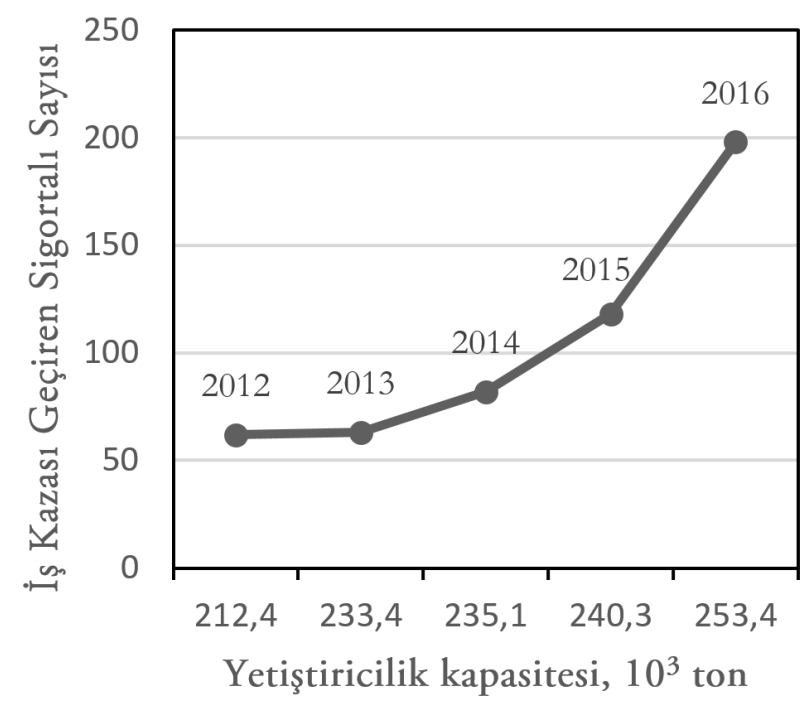

Yetiştiricilik, FAO tarafından dünyada en hızlı büyüyen gıda sektörü olarak belirlenmiş olup, dünyada olduğu gibi ülkemizde de hızla büyümüştür. Tablo 5’ de, 2015- 
Tablo 5: Su ürünleri yetiştiriciliğinde iş kazası geçiren ve meslek hastalığına tutulan sigortalı sayıları

\begin{tabular}{|c|c|c|c|c|c|c|c|c|c|c|c|c|}
\hline & \multicolumn{4}{|c|}{2015} & \multicolumn{4}{|c|}{2016} & \multicolumn{4}{|c|}{2017} \\
\hline & \multicolumn{2}{|c|}{$\begin{array}{c}\text { İş kazası } \\
\text { geçiren } \\
\text { sigortalı sayısı }\end{array}$} & \multicolumn{2}{|c|}{$\begin{array}{c}\text { Meslek } \\
\text { hastalığına } \\
\text { tutulan sigortalı } \\
\text { sayısı }\end{array}$} & \multicolumn{2}{|c|}{$\begin{array}{c}\text { İş kazası } \\
\text { geçiren sigortalı } \\
\text { sayısı }\end{array}$} & \multicolumn{2}{|c|}{$\begin{array}{c}\text { Meslek } \\
\text { hastalığına } \\
\text { tutulan sigortalı } \\
\text { sayısı }\end{array}$} & \multicolumn{2}{|c|}{$\begin{array}{c}\text { İş kazası } \\
\text { geçiren } \\
\text { sigortalı sayısı }\end{array}$} & \multicolumn{2}{|c|}{$\begin{array}{c}\text { Meslek } \\
\text { hastalığına } \\
\text { tutulan sigortal } \\
\text { sayısı }\end{array}$} \\
\hline & 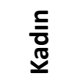 & 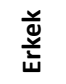 & $\begin{array}{l}\text { 吾 } \\
\stackrel{\Xi}{\Xi}\end{array}$ & 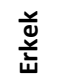 & 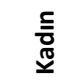 & 莺 & 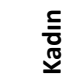 & 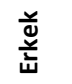 & 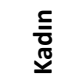 & 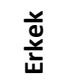 & 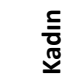 & 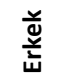 \\
\hline Deniz ürünleri yetiştiriciliği & 6 & 95 & 0 & 0 & 28 & 162 & 0 & 0 & 14 & 210 & 0 & 0 \\
\hline Tatlı su ürünleri yetiştiriciliği & 4 & 13 & 0 & 0 & 3 & 5 & 0 & 0 & 5 & 16 & 0 & 0 \\
\hline YETiŞTiRiciLiK (TOPLAM) & \multicolumn{2}{|c|}{118} & \multicolumn{2}{|c|}{0} & \multicolumn{2}{|c|}{198} & \multicolumn{2}{|c|}{0} & \multicolumn{2}{|c|}{245} & \multicolumn{2}{|c|}{0} \\
\hline
\end{tabular}

2017 yılları arası, iş kazası geçiren ve meslek hastalığına tutulan sigortalı çalışanların dağılımları görülmektedir[13]. Açık denizlerde gerçekleştirilen yetiştiricilikte, iç sulardakilere göre daha fazla çalışan iş kazasına uğramıştır. İş kazası geçiren erkek çalışan sayısı, kadınlara oranla daha fazladır. Yetiştiricilik; beden gücü, makina ve hava koşullarına bağlı olduğundan; kas iskelet sistemi hastalıkları, işitme kaybı, deri ve cilt hastalıkları karşılaşabilecek meslek hastalıkları arasındadır[12].

Yetiştiricilikle ilgili bir diğer birim, üretimin ilk basamağı olan kuluçkahanedir.

Kuluçkahanelerde, yumurtadan yavru balığa farklı evrelerde farklı yemler (toz yem, plankton, artemia gibi canlı yemler) kullanılmaktadır. Bu açıdan yem sektörü, yetiştiricilikte önemli bir yer tutmaktadır. Kuluçkahanelerde anestezi ve aşılama uygulamalarında; ilaç (örneğin sedatif maddeler) ve kimyasallarla temas kaçınılmazdır. Bu durum alerji, enfeksiyon, deri ve solunum yolu hastalıklarına yol açabilmektedir. Kuluçkahanelerde, bakteriyel enfeksiyonlarla sık karşılaşılmaktadır. Dolayısıyla havuzlarda su kalitesine dikkat edilmeli, üretimin her aşamasında kontrol sağlanmalı, düzenli ve etkin izlenebilirlik oluşturulmalıdır. Yer altı/deniz suyu temininde kullanılan pompalar, havalandırma oksijen tankı, ısıtma ve soğutma sistemleri, jeneratör, kapalı devre sistemleri, kuluçkahanelerde kullanılan makinalar arasındadır. Bu bağlamda, kas iskelet hastalıkları, işitme kaybı, solunum hastalıkları, deri ve cilt hastalıkları olası olmaktadır. Ağ kafeslerde yapılan yetiştiricilikte; onarım, değişim, temizleme ve rutin kontroller için dalma söz konusudur. Dalma sırasında, hiperbarik koşullar "Vurgun" olarak bilinen meslek hastalığına yol açabilmektedir. Ağ değişim-temizleme sırasında, kimyasal ajanlara maruz kalınmaktadır. Ağ, yem ve balık konteynerleri gibi yük kaldırma gerektiren işlemlerde, kas iskelet sistemi hastalıklarına rastlanmaktadır[14, 17].

Yetiştiricilik, 2017 yllında toplam üretimin \% 43,8' ine ulaşmışıı[3]. Yetiştiricilik ile yem arasında doğrusal ilişki bulunduğundan, yetiştiriciliğin gelişmesi balık yemi üretimini arttıracaktır. Balık yemi üretimimiz, 2017 yılında \% 11 büyüme ile 513 bin ton olarak gerçekleşmiştir. Karma yem üretimimiz ise 22.4 milyon ton olup, balık yemi payı $\% 2.3$ ' tür[18]. Büyük mekanizasyon gerektiren yem sektöründe kas iskelet sistemi hastalıklarına sıkça rastlanmaktadır. Yem, sucul organizmaların tür ve biyolojik gelişim evrelerine uygun kompozisyonda hazırlanmalıdır. Protein, karbonhidrat ve yağ içeriği açısından iyi formüle edilen yem, maliyet ve çevre kirliliğini en aza indirger. Canlının, yemden maksimum fayda sağlaması ve yem dönüşüm ora- 
nının artması önemlidir[15]. Yem; protein kaynağı olarak balık unu, balık yağı, katkı maddeleri, vitamin ve mineraller içermektedir. Buğday, kepek, kolza, soya, zeytinyağı, keten tohumu, ayçiçeği ve hurma yağı gibi alternatif bitkisel kaynaklarda yem hazırlamada kullanılmaktadır. Yem sektöründe; göz, solunum sistemi hastalıkları, "weil hastalığı" (leptospiroz; halk arasında sarılık olarak bilinmektedir) karşılaşılan meslek hastalıklarıdır. Hayvanlar tarafından yayılan bakteriyel bir enfeksiyon türü olan weil hastalığı, fareyle temas eden su ve yem ile insanlara bulaşabilmektedir. Ayrıca balıkların hastalanmasını önlemek için yeme ilave edilen ilaç-kimyasallar alerji riskini artırmaktadır[19].

\section{Su Ürünleri İşleme Tesislerde Karşılaşabilecek İş Kazaları ve Meslek Hastalıkları}

Dünya toplam su ürünleri üretiminin \% 81' i gıda, kalan \% 19' luk kısmı ise balık unu-balık yağı olarak tüketildiği belirtilmiştir. Su ürünleri deyince ilk akla gelen ve dünyada en sık tüketilen balık; sofralarımızda taze, konserve, fileto, tütsülenmiş, ançüez, suşi gibi farklı şekillerde yerini almaktadır[1].

Balık işleme tesislerinde; deri, pul, iç alma, kılçık ayırma, fileto çıkarma, dilimleme, kafa çıkartma, son kuyruk kesme işlemleri, el veya makine ile gerçekleştirilmektedir. $\mathrm{Bu}$ işlemler sırasında kullanılan, kesici aletler, sivri parçalar ve makinalar sıklıkla iş kazalarına (kesik, kopma, yaralanma) yol açmaktadır. Balık işleme makinaları, işitme kaybına neden olmaktadır. Önlem olarak koruyucu kulaklık kullanımı gereklidir. Sürekli nemli ve ıslak ortamda çalışma cilt hastalıklarına (örneğin, egzama) neden olmaktadır. Karides, yengeç ve istakoz gibi kabuklu deniz canlılarının işlenmesi sırasında ortaya çıkan protein tozları mesleki astıma yol açmaktadır. Tendinit ve Karpal Tünel Sendromu, bu sektörde en sık karşılaşılan kronik kas iskelet sistemi hastalıklarıdır. Tendinit, kemiği kaslara bağlayan tendo- nun iltihaplanması ve tahriş olmasından kaynaklanan bir çeşit kas hastalığıdır. Karpal Tünel Sendromu, ağrı ve uyuşma belirtileri gösteren, elin içinden geçen medyan sinirin sıkışmasıdır[7, 20].

\section{IV. ÖNLEMLER}

İş sağlığı ve güvenliği’nin amaçlarından biri, kaza yaşanmadan tedbir alma ve işyerinde güvenlik bilincinin geliştirilmesidir. İş esnasında maruz kalınan mesleki riskler, uzun vadede meslek hastalıkları olarak karşımıza çıkmaktadır. Güvenlik kültürü, iş ve sosyal yaşamda güvenliği içerir, küçük yaşlarda ailede aşılanır, ilköğretimle pekiştirilir ve toplumun bilinçlenmesi sağlanır. Örneğin; sigara kullanımının az olması, güvenlik kültürünün toplumsal boyutta ne derece benimsendiğinin bir göstergesidir. Sigara kullanımının, kanser riskini arttırdığı bilinmektedir. Balıkçılar, deri ve cilt hastalıklarından korunmak için, koruyucu krem ve pomad kullanmalıdır.

İş kazaları ve meslek hastalıklarını önlemenin en etkin yolu kişisel koruyucu donanım (KKD) kullanılmasıdır. Kişisel güvenliğin ayrılmaz bir parçası olan koruyucu gözlük, maske, kulaklık, giysi-eldiven, baret, ayakkabı vb. iş yürütümü sırasında kullanım kılavuzuna uygun bir şekilde giyilmelidir. Çalışanlara KKD tedarik etmek işverenin yükümlülüğünde olmakla birlikte, koruma sağlayacak şekilde doğru kullanımı bireyin güvenlik kültürü ile ilgilidir. Örneğin gürültü, işitme kaybına neden olan bir meslek hastalığı olup, gürültünün ortama yayılması toplu koruma sağlayacak teknik yöntemlerle ve iş organizasyonuyla önlenemiyorsa, koruyucu kulaklık kullanılması gereklidir[21].

Ülkemizde, su ürünleri sektöründe çalışanlara yönelik koruyucu tedbirlerin alınması, sigorta ve sağlık sisteminde iyileştirmeler, ücretsiz bakım ve tarama hizmetleri gibi destekleyici faaliyetler, veri kayıt mekanizmasını işler hale getirerek yaşanan iş kazaları ve meslek hastalıklarının önlenme- 
sinde katkı sağlayacaktır.

\section{SONUÇ}

Su ürünleri sektöründe özellikle avcılık ve yetiştiricilikte karşılaşılan, boğulma, kayıp düşme, damar kesiği, kopma, kırık-çıkık, sıkışma vb. vakalar iş kazası kapsamında değerlendirilmektedir. Bu çalışma, 5510 sayılı SGK Kanunu kapsamında meslek hastalığı olarak belirlenen hastalıkların avcılık, yetiştiricilik, işleme ve yem endüstrilerinde nasıl ortaya çıkabileceği ve çözüm önerileri sunulmuştur. ILO' nun 2018 yilı tahminlerinde; dünyada her yıl meydana gelen iş kazası sonucu ölümlerin 6,3 katı ölüm, meslek hastalıkları sonucunda meydana gelmektedir. Ülkemizde meslek hastalığına yakalanma riski tüm sektörlerde üzerinde durulması gereken bir konudur. Meslek hastalıklarının tanı ve bildirimi aşamasındaki eksiklikler "gerçek" durumun bilinmesini engellemektedir. Meslek hastalıklarının; ailevi, sosyal, toplumsal ve ekonomik boyutu vardır. İş kazaları gibi meslek hastalıkları da; eğitim, bilinç ve kişisel koruyucu donanım kullanımıyla en aza indirilebilir. Böylece iş, kişi, ekonomi bazında kayıpların (zaman, emek, para) önüne geçilebilir. Ülkemizde, su ürünleri sektörünün büyümesiyle orantılı olarak, sektörde meydana gelen iş kazaları sayıları artmışıิı. Meslek hastalıkları istatistiklerine bakıldığında ise, meslek hastalıklarının tespit edilmesinin güçlügü̈, bazı meslek hastalıklarının uzun dönemde ortaya çıkması ve çalışanların bu sırada sektör değiştirmesi, bazı durumlarda yapılan iş ile hastalık arasında sağlıklı bağlantılının kurulamaması (fiziksel, kimyasal, biyolojik, psikolojik etkenlerin hatırlanmaması) ve bazı iş yerlerinin sigortasız eleman çalıştırması sayıların doğru belirlenmesini zorlaş̧ırmaktır. Meslek hastalıkları ve işle ilgili hastalıklar gelişmeden veya erken evrede tanınarak önlenebilir olup, işveren ve çalışanların bilgi ve hassasiyetlerinin sağlanması önemlidir.

\section{KAYNAKLAR}

[1] Şahinöz, E., Doğu, Z., \& Aral, F. (2017). Türkiye ve Dünya' da Su Ürünlerinin Mevcut Durumu. Kent Kültürü ve Yönetimi Hakemli Elektronik Dergi, 10 (4), 466-476.

[2] TÜIK (2017). Su Ürünleri 2017. Erişim Tarihi: 31.07.2018, PreHaberBultenleri.do?id=27669

[3] TÜİK (2020). Su Ürünleri İstatistikleri 2020. Erişim Tarihi: 18.02.2020, https://www.tarimorman.gov.tr/ BSGM/Belgeler/Icerikler/Su-Urunleri-İstatistikleriMart-2019.pdf

[4] Yeşilayer, N., Akın, Ş., \& Coşkun, M. (2016). Su Ürünleri Mühendislerinin Sorunları ve Çözüm Önerileri, Gaziosmanpaşa Bilimsel Araştırma Dergisi, (13), 1-12.

[5] Anonim (2017). İş Kazası Meslek Hastalıkları, Erişim Tarihi: 18.02.2020, tuisag.com/2017-yili-is-kazasi-meslek-hastaliklariistatistikleri/

[6] Anonim (2012). Başbakanlık Mevzuatı Geliştirme ve Yayın Genel Müdürlüğü. Erişim Tarihi: 01. 4. 2019, . http://resmigazete.gov.tr/eskiler/2012/06/20120630 $-1 . h \mathrm{tm}$

[7] Anonim (2013). Meslek Hastalıkları. Çalışma ve Sosyal Güvenlik Eğitim ve Araştırma Merkezi (ÇASGEM).

[8] TÜİK (2018). Sağlık İstatistikleri 2018. Erişim Tarihi: 13.03.2019, https://www.tuik.gov.tr

[9] Anonim (a), Mesleki kanserler. Erişim Tarihi:18.03.2019, content.lms.sabis.sakarya.edu.tr/ Uploads/66395/33361/mesleki_kanserler.pdf

[10] Anonim (b), Mesleki kanserler. Erişim Tarihi:18.03.2019, http://politeknik.org.tr/meslekikanserler-calisirken-kanser-oluyoruz-dr-coskuncanivar/

[11] Şık, A. (2017). Su Ürünleri Tesislerinde İş Sağllğı ve Güvenliği Uygulamaları. İzmir Katip Çelebi Üniversitesi, Fen Bilimleri Enstitüsü, Yüksek Lisans Tezi, 139 sayfa, İzmir.

[12] Perçin, F. (2017). İzmir Balıkçılarında Kazalar ve Meslek Hastalıkları: İzmir Balıkçılığı. Editörler: Kınacıgil, H.T., Tosunoğlu, Z., Çaklı, Ş., Bey, E., \& Öztürk, H. İzmir Büyükşehir Belediyesi 304 sayfa, Konak, İzmir

[13] Anonim, İş kazası ve meslek hastalıkları istatistikleri. Erişim Tarihi: 05.04.2019, http://tuisag.com/is- 
kazasi-meslek-hastaliklari-istatistikleri/

[14] Anonim, Dekompresyon (Vurgun) Hastalığı. Erişim Tarihi: 14.03.2019, http://www.ameliyat.com/ dekompresyon-vurgun-hastaligi-d186/

[15] Demir, O. (2011). Türkiye Su Ürünleri Yetiştiriciliği ve Yem Sektörüne Genel Bakış-II. Eğirdir Su ürünleri Fakültesi Dergisi, 7(1), 39-49.

[16] Anonim (2017). Su Ürünleri Raporu, Ziraat Mühendisleri Odası. Erişim Tarihi: 13.03.2019, http:// www.zmo.org.tr/genel/bizden_detay.php?

kod=27302\&tipi $=17 \&$ sube $=0$

[17] Çobanoğlu, F., Çoban, D., Yıldırım, Ş., Kırım, B., Tunalıŏlu, R. \& Cankurt, M. (2015). Deniz Balığı Yetiştiricilik Sistemlerinde Üreticilerin Risk Algıları ve Risk Yönetim Stratejileri. Tarımsal Ekonomi ve Politika Geliştirme Enstitüsü (TEPGE), (Adnan Menderes Üniversitesi Bilimsel Araştırma Projeleri Birimi ZRF-12005 Nolu Proje Sonuç Raporu).

[18] Anonim (2018). Yem Magazin, Türkiye Yem Sanayicileri Birliği, Mart 2018, Sayı 81. Erişim Tarihi: 13.03.2019, http://yem.org.tr/YemMagazin/

[19] Atayeter, S., \& Atar, H. H. (2013). TS 18001 İş Sağlığı ve Güvenliği Yönetim Sistemi ve Yüzer Kafes Balık Üretim Tesislerinde İş Sağlığı ve Güvenliği. Yunus Araştırma Bülteni, 1, 27-36

[20] Atayeter, S., \& Terzioğlu, E. (2009). Bir Su Ürünleri İşleme Tesisinde İş Sağlığı ve Güvenliği Risk Analizi Uygulaması. Gıda, 24(5), 287-293.

[21] Anonim, Meclis Araştırması Komisyonu Raporu, Gemi İnşa Sanayisindeki İş Güvenliği ve Çalışma Şartları Sorunlarının Araştırılarak Alınması Gereken Önlemlerin Belirlenmesi. TBMM, 23. Dönem, 2.Yasama Yilı, Temmuz 2008, 295 sayfa, Ankara. 